\title{
Settlement, growth and reproduction in the deep-sea wood-boring bivalve mollusc Xylophaga depalmai
}

\author{
Paul A. Tyler ${ }^{1, *}$, Craig M. Young ${ }^{2}$, Fiona Dove ${ }^{1}$ \\ ${ }^{1}$ National Oceanography Centre, University of Southampton, European Way, Southampton SO14 3ZH, UK \\ ${ }^{2}$ Oregon Institute of Marine Biology, Boat Basin Road, Charleston, Oregon 97420, USA
}

\begin{abstract}
Experimental panels of spruce and oak deployed at 3 and 6 mo intervals over a period of several years at ca. $500 \mathrm{~m}$ depth in the NE Tongue of the Ocean, Bahamas, were rapidly colonised by the wood-boring bivalve Xylophaga depalmai Turner, 2002. Colonisation of the wood occurred year-round but there was evidence that it was more intense in the summer months. The population structure of $X$. depalmai was the same for spruce and oak, although there was evidence that the female population structure in each wood type differs significantly from the male population structure. $X$. depalmai grew at a mean rate of ca. $0.03 \mathrm{~mm} \mathrm{~d}^{-1}$. Gametogenesis was initiated in individuals of $X$. depalmai in all deployments and was active by Day 59. Egg size was ca. $40 \mu \mathrm{m}$ diameter and fecundity was high. Once initiated, gametogenesis was quasi-continuous and gamete density suggested that spawning was periodic. There was no difference in gametogenesis in individuals from different wood types.
\end{abstract}

KEY WORDS: Wood $\cdot$ Xylophaga $\cdot$ Growth $\cdot$ Reproduction $\cdot$ Settlement $\cdot$ Deep sea

\section{INTRODUCTION}

Wood is an essentially ephemeral resource in the deep sea. Flowering plants are rare in the ocean, and none have a woody structure. As a result, all wood is allochthonous, being carried into the sea by river flow from inland areas, by offshore transport from fringing forests or, over the last $5000 \mathrm{yr}$, from wooden ships. Thiel (2003) calculated that 3701 ships sank between 1971 and 1990 alone. Once in the sea, wood does not remain intact. Natural and experimentally-emplaced wood disappears rapidly (Turner 1973). Seventy years after the sinking of the 'Titanic', (Ballard 1987) noted the complete destruction of treated deck pine, and the almost complete disappearance of oak on the 'Grand staircase', both caused by wood-boring organisms. In contrast, the teak was in "almost mint condition" (Ballard 1987, p 208).

Among the main metazoan agents for wood degradation in the sea are bivalve molluscs of the genus Xylophaga. Although the genus is found in shallow water, it is particularly diverse in the deep-sea and many species of deep-sea Xylophaga were described by Knudsen (1961) and in a posthumous publication by Turner (2002). Interest in this genus has been driven partly by the economic loss caused by degradation of lobster traps and other wooden structures placed in the sea (Junqueira et al. 1991). As a result there is a considerable literature on the systematics, settlement and growth of species of Xylophaga (Turner 1973, Norman 1977, Haderlie 1983, Berg et al. 1987, Romey et al. 1991, 1994) and other wood-boring bivalves (Ecklerbarger \& Reish 1972a,b, Mann \& Gallager 1985) at shelf depths. Purchon (1941) published the first monographic treatment of the biology of Xylophaga by describing the functional morphology of $X$. dorsalis collected from driftwood around the British Isles. Purchon (1941) described $X$. dorsalis as a protandric hermaphrodite. Knudsen's (1961) monograph of deep-water species of Xylophaga demonstrated a variety of reproductive patterns from broadcasting to brooding, the 
former dominating in shallow water and the latter in deep water. Fertilisation and larval development in $X$. atlanticum was examined by Culliney \& Turner (1976). Turner (1973) suggested that deep populations of Xylophaga spp. were 'opportunistic' and that there may be a seasonal component to the availability of wood in the deep sea related to the spring thaw or local hurricane seasons (Tyler 1988). A seasonal component to the recruitment of $X$. atlanticus was observed on wood panels deployed at shelf depths from 41 to $234 \mathrm{~m}$ along the eastern seaboard of the US (Berg et al. 1987). Berg et al. (1987) commented on the poor state of knowledge of the life history of Xylophaga species. Although they had panels deployed on a seasonal basis, these authors determined settlement rates only.

Natural woody substrata include coconuts and other 'woody' fruits, as well as the rhizomes of seagrasses (Wolff 1979). These are colonised by deep-sea organisms (Knudsen 1961, Wolff 1979), although colonisation can be very variable in space and time. As part of a long-term suite of experiments examining larval settlement at bathyal depths in the Bahamas, we deployed wood at regular intervals from 1992 to 1994. The wood was rapidly colonised by an undescribed species of Xylophaga. Initially, we believed there might be 2 species of Xylophaga on our panels, as the mesoplax of different individuals showed considerable variation (Fig. $1 \mathrm{~A}, \mathrm{~B})$. The mesoplax of the genus Xylophaga is considered a very conservative morphological character at the species level (Knudsen 1961), and it was only with the publication of a posthumous monograph that the species we found was finally described (Turner 2002, p 253-256). The species (Xylophaga
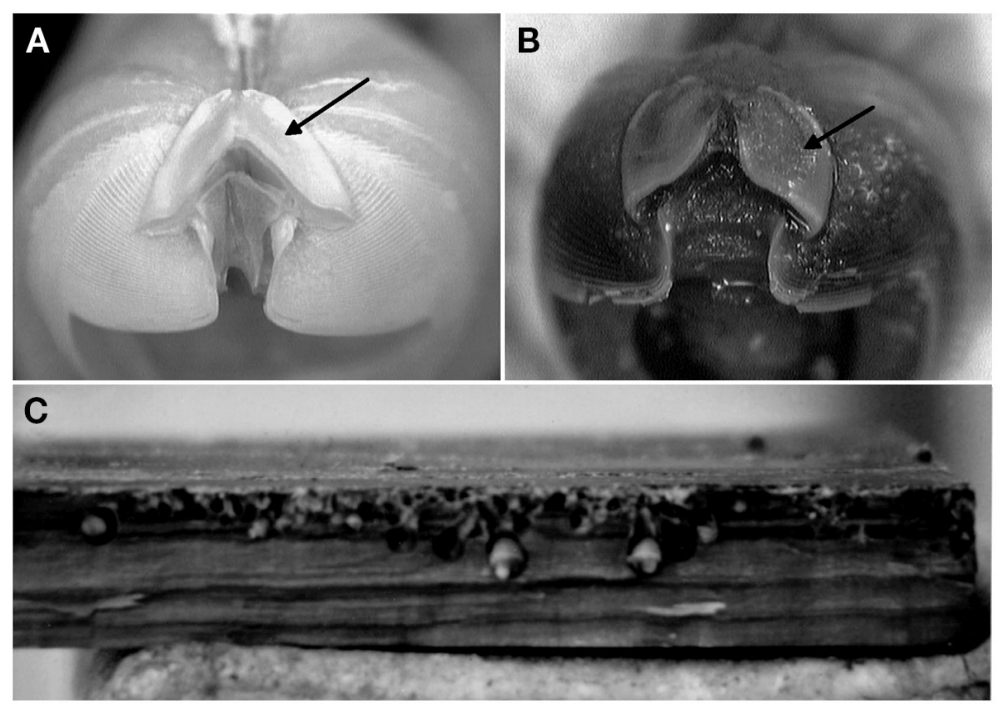

Fig. 1. Xylophaga depalmai. $(\mathrm{A}, \mathrm{B})$ Two specimens from sampling site showing the extremes of variation in the mesoplax (arrowed) described by Turner (2002); (C) evidence of boring by X. depalmai after 3 mo depalmai Turner, 2002) is the only species of the genus Xylophaga with a highly variable mesoplax, although the many individuals described from this species have many other conservative characters in common. Turner (2002) described this species as having a depth range of 30 to $174 \mathrm{~m}$. As a result of Turner's description we are able now to publish our data and to extend the depth range by several hundred metres.

The aim of our study was to establish a long-term bathyal sampling programme for Xylophaga depalmai to determine (1) the rate and periodicity of settlement; (2) growth rates to reproductive maturity, and (3) rate and periodicity of gametogenic development

\section{MATERIALS AND METHODS}

In situ experiments were conducted between 480 and $520 \mathrm{~m}$ depth off Southwest Reef (Latitude

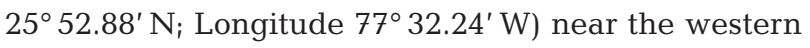
end of New Providence Island, in the northeasternmost corner of the Tongue of the Ocean, Bahamas. The site was marked by a $12 \mathrm{kHz}$ pinger and all operations at the site were conducted using 'Johnson Sea-link' submersibles. For physical oceanographic data, two Anderaa current meters were deployed near the site, one on the seabed and one $5 \mathrm{~m}$ above the seabed (Young et al. 1993). These were serviced approximately every three months, at which time the current direction and speed were downloaded. Mean average temperature was 10 to $13^{\circ} \mathrm{C}$ at the site.

The wooden settlement panels, of spruce and oak, each $14 \times 14 \times 1 \mathrm{~cm}$, were attached to blocks of natural limestone $30 \times 30 \times 5 \mathrm{~cm}$ by plastic tie wraps. The amount of wood deployed may have an effect on the wood-boring activity of teredinids (Junqueira et al. 1991). The size selected for the present study was compatible with the logistics of submersible deployments. At least three replicate blocks were deployed on each cruise, together with other settlement substrata (palm fronds for limpets and fibrous mats for sipunculans) in a randomised block design. Blocks with wood panels were deployed for ca. 3 or ca. 6 mo (Fig. 2), the vagaries of ship-time planning allowing some variation about the nominal 90 or 180 d planned deployment times. On retrieval, the blocks were released from the limestone block (Fig. 1C), examined in a living state under a dissecting microscope, then submerged in separate containers of $5 \%$ formalin in seawater and subsequently transferred to $70 \%$ isopropanol for transport and long-term storage. 


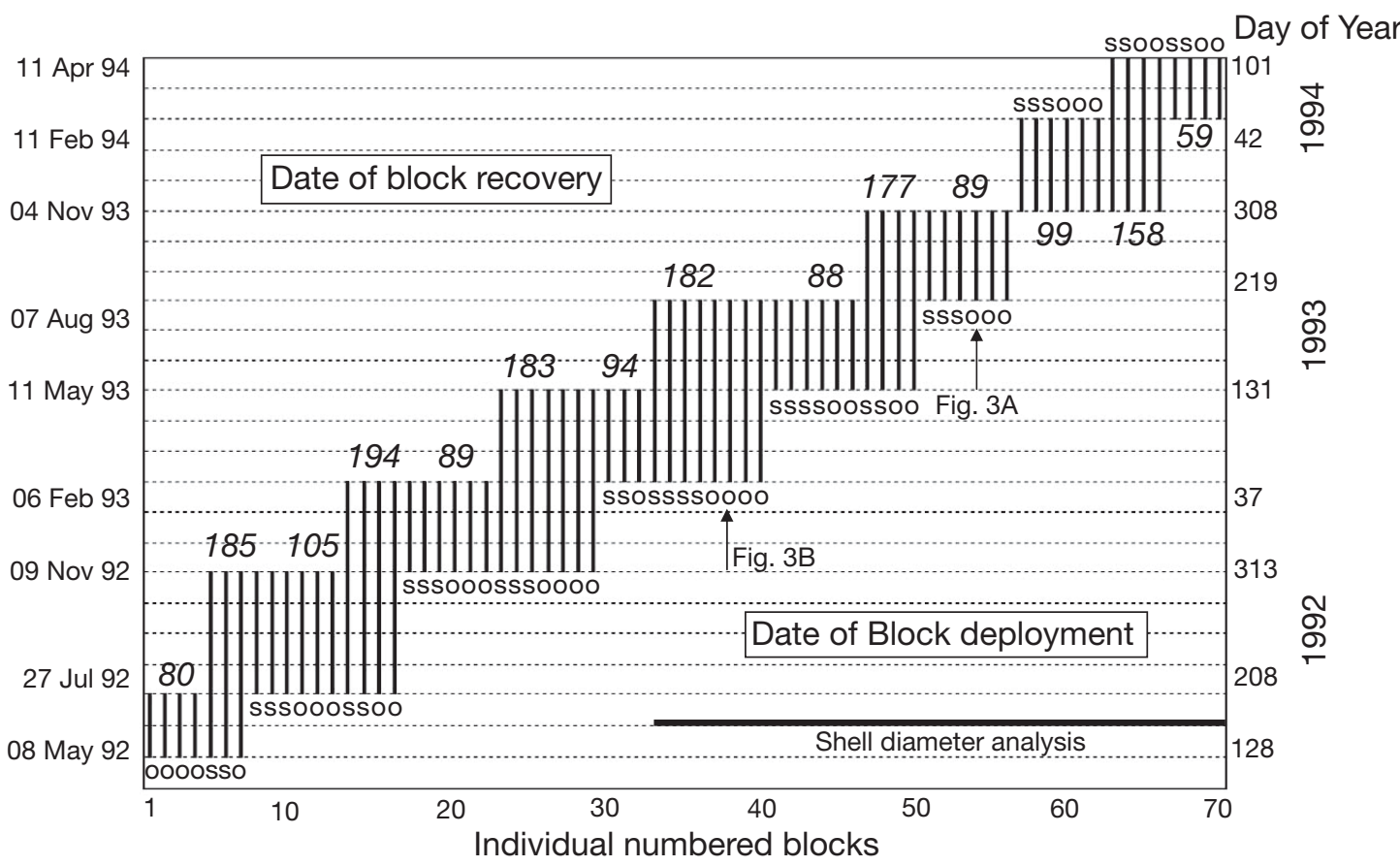

Fig. 2. Deployment and recovery schedule (actual date and day of year), and no. of days of deployment (italics), of individual blocks of spruce (s) and oak (o). Vertical lines represent deployment period for each block. Blocks 34 to 71 were used in population analysis. The 2 block X-rays in Fig. 3 are indicated (arrows). All deployments were sampled for gametogenic examination except from May to November 1993

In the laboratory, we initially attempted to remove all individuals of Xylophaga depalmai from the blocks. Although partially successful, this resulted in many damaged specimens. From February 1993 (Fig. 2) each deployed block was X-rayed, and the radiograph used to measure the diameters of the individuals in the block (Fig. 3). Diameter was selected as $X$. depalmai is almost spherical and shows variable orientation in the wooden block. Dead $X$. depalmai disarticulate rapidly and were excluded from measurements. Adult diameter was used to plot size/ frequency distributions and to determine growth rates. Individual $X$. depalmai from the entire sampling period, representing a size range from smallest to largest, were then removed from the blocks. Individuals were wet-weighed, decalcified in Bouin's solution, and wet-weighed again. Ten individuals from each block were dehydrated, cleared, embedded in paraffin wax, then sectioned at $7 \mu \mathrm{m}$ and stained with Masson's trichrome. A minimum of 50 oocytes from each individual were measured using the Jandel SigmaScan Pro 4 programme. Mean oocyte density was determined by counting the number of oocytes in 5 random squares, each of $22500 \mu^{2}$.

The number of individuals in the blocks was tested against date of deployment, and day of the year of deployment and of recovery using the Kruskal-Wallis test, as a non-parametric ANOVA, in Sigmastat Version 3. Sex ratios were compared with an even distrib-
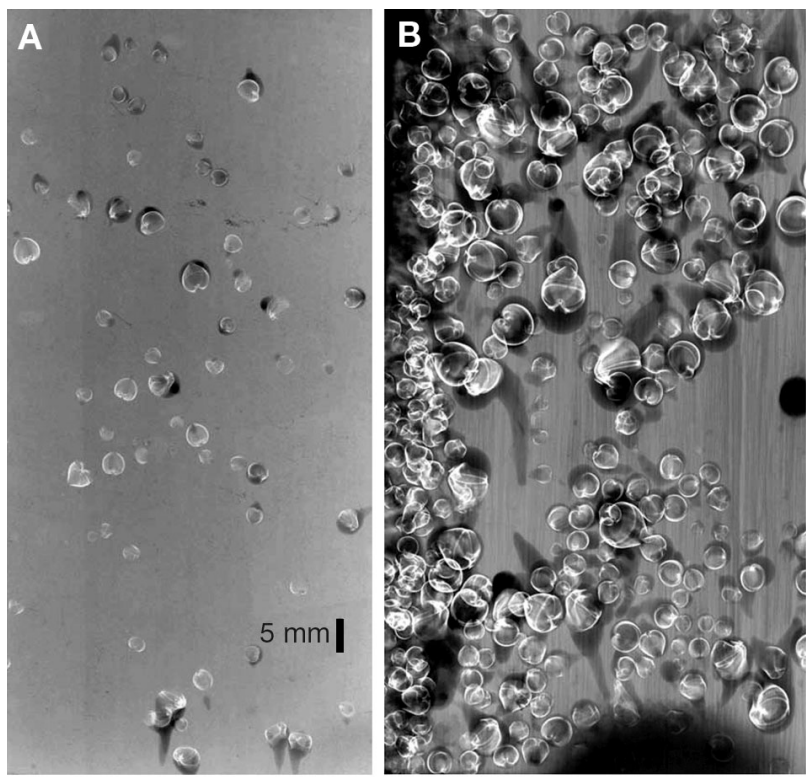

Fig. 3. Xylophaga depalmai. X-radiographs after (A) 3 mo (Block 54) and (B) 6 mo (Block 39)

ution using the $\chi^{2}$ goodness of fit test. Data were plotted in Sigmaplot Version 9. The curve-fitting function in Sigmaplot Version 9 was used to fit curves to the growth data. Growth curves were compared using the Student's $t$-test for differences between 2 population regression coefficients (Zar 1996). 


\section{RESULTS}

Replicate sets of oak and spruce settlement panels were deployed for periods ranging from 59 to $194 \mathrm{~d}$ (Fig. 2). A total of 71 wooden blocks were deployed and recovered. In both 3 and 6 mo deployments, wood remained attached to the limestone block. Two 'sacrificial' blocks left for 13 months disappeared completely.
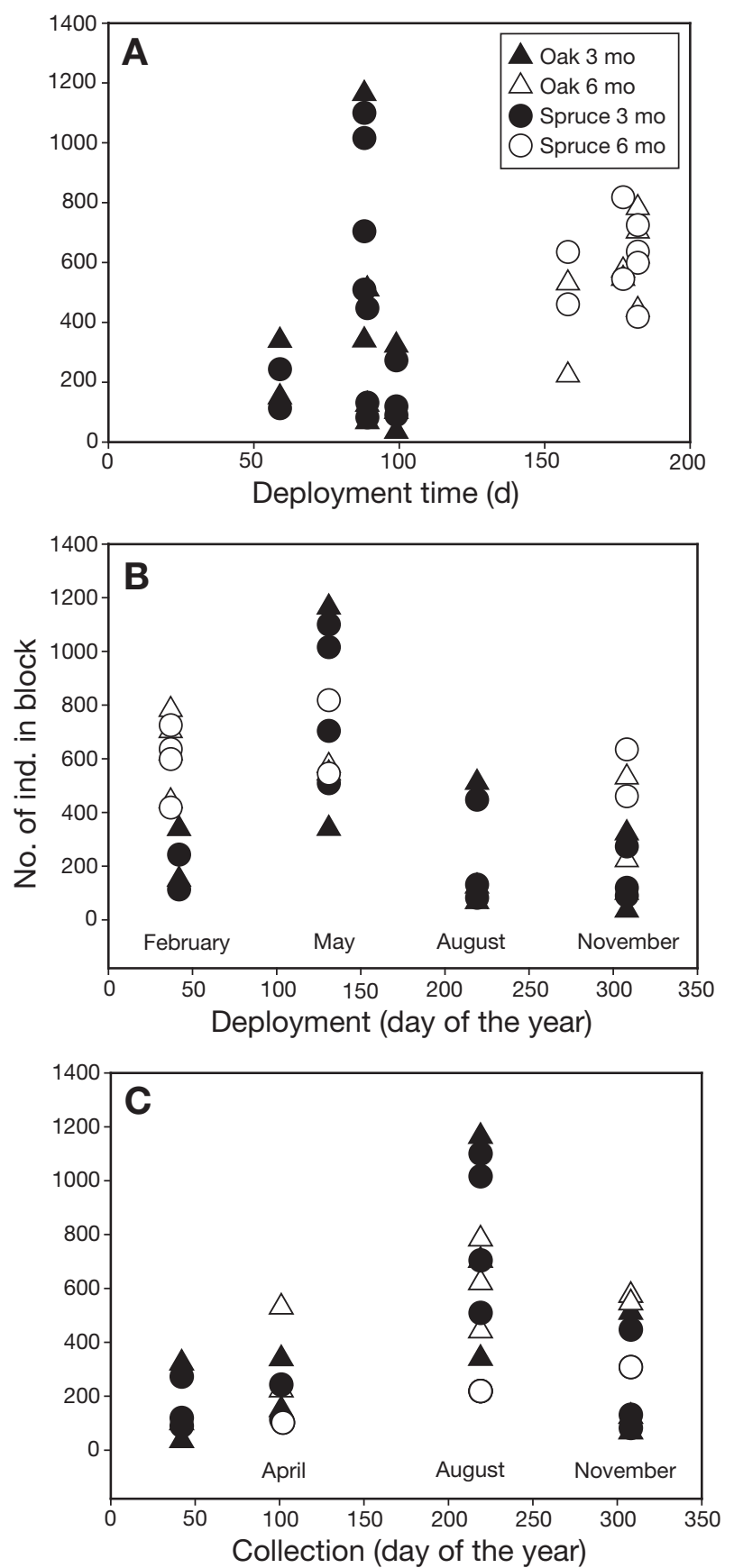

Fig. 4. Xylophaga depalmai. Recruitment in relation to (A) no. of days of deployment, (B) deployment day, and (C) recovery day

\section{Recruitment and growth}

The number of surviving individuals found in each wooden block (at recovery) varied from a high of 1164 in an oak block deployed for 3 mo to a low of 35 individuals in another oak block deployed for the same length of time (Fig. 4A). The number of surviving individuals varied significantly with length of deployment (Kruskal-Wallis, $H=9.351, \mathrm{p}=0.025$ ) and season of deployment $(H=16.199, \mathrm{p}=0.023)$ (Fig. 4B). Oak blocks showed no statistically significant difference with season of deployment $(H=7.340, p=0.062)$ but spruce did $(H=9.156, \mathrm{p}=0.027)$. There was also considerable variation in the number of surviving individuals in blocks in relation to the day of recovery $(H=$ 17.72, $\mathrm{p}=0.013$ ) (Fig. 4C); however, the highest number survived during the summer months of June and July, and the lowest number during the winter months of November to February. The number of surviving individuals in 6 mo blocks was less variable than in 3 mo blocks. Combined with the population analysis (below) this difference in variance suggests that many smaller juveniles are lost from the population.

Once settled, there was rapid growth of individuals. At 3 mo, mean individual diameter in any block varied from 0.45 to $2.02 \mathrm{~mm}$ in spruce and from 1.48 to $2.7 \mathrm{~mm}$ in oak (Fig. 5). At 6 mo the individual means were 3.5 to $4.45 \mathrm{~mm}$ for spruce and 4.08 to $5.08 \mathrm{~mm}$ for oak (Fig. 5). Power curves fitted separately to the spruce and oak means showed no statistically significant difference $(t=0.06 ; \mathrm{df}=36)$.

The population structure of Xylophaga depalmai showed rapid growth in all individuals in all blocks. In

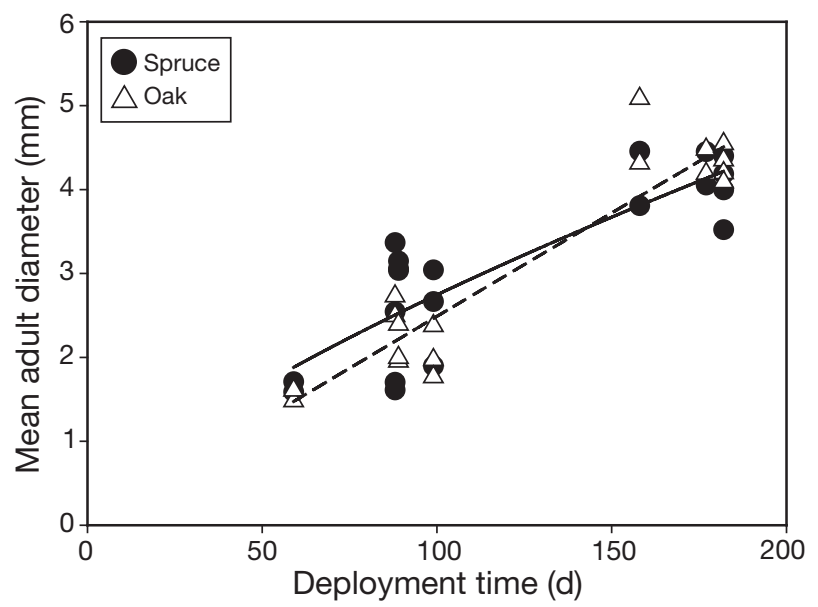

Fig. 5. Xylophaga depalmai. Mean adult diameter $(\mathrm{mm})$ in relation to days of deployment of wood blocks. Power curves fitted to different wood types (solid line $=$ spruce; dashed line $=$ oak). No statistically significant difference was found between the fitted curves (see 'Results'). (Regression for spruce: $y=0.1013 x^{0.7166}, F=50.04, \mathrm{p}=<0.0001$; for oak: $y=$ $0.0258 x^{0.9925}, F=117.79, \mathrm{p}=<0.0001$ ) 
both spruce and oak, the maximum size after 3 mo was $6 \mathrm{~mm}$ shell diameter, although the shortest block deployments $(59 \mathrm{~d})$ had much smaller individuals (Fig. 6A,B). These data suggest a growth rate of $0.067 \mathrm{~mm} \mathrm{~d}^{-1}$, assuming that larvae settled on the first day of deployment. However, the mean growth rate at 3 mo was $0.0288 \mathrm{~mm} \mathrm{~d}^{-1}$ for spruce, $0.0248 \mathrm{~mm} \mathrm{~d}^{-1}$ for oak. The maximum diameter achieved in the 6 mo deployed blocks was $11 \mathrm{~mm}$ (Fig. 6C,D) equating to a growth rate of $0.060 \mathrm{~mm} \mathrm{~d}^{-1}$, although mean growth rates for individuals collected after 6 mo were $0.0235 \mathrm{~mm} \mathrm{~d}^{-1}$ for spruce and $0.0252 \mathrm{~mm} \mathrm{~d}^{-1}$ for oak. There was no statistically significant difference among growth rates based on wood or deployment time except between spruce at 3 and $6 \mathrm{mo}(t=2.19, \mathrm{p}=0.04, \mathrm{n}=19)$.

Comparison of the population structure between the 3 and 6 mo deployments suggests that recruitment declines with time. Were recruitment continuous, we would expect to see peaks in the small size classes, but these did not occur. As the populations in the blocks were reproducing (see next subsection), this suggests that recruits did not come directly from the local populations, and that zygotes produced are advected away from their parents.

There was a strong power relationship between shell diameter and wet weight (spruce $y=-0.6014+$ $1.5175 \ln x, F=532.07, \mathrm{p}=<0.0001 ;$ oak $y=0.8641+$ $1.1019 \ln x, F=284.83, \mathrm{p}=<0.0001)$. Curves fitted to the spruce and oak data separately showed no statistically significant difference $(t=1.93$; df $=98)$.

\section{Reproduction}

All individuals $>2 \mathrm{~mm}$ in diameter $(>3.5 \mathrm{mg}$ wet weight; $\mathrm{n}=250$ ) contained gonads in development (i.e. they were reproductively active). Even for the shortest deployment in our study (59 d), all individuals exam-
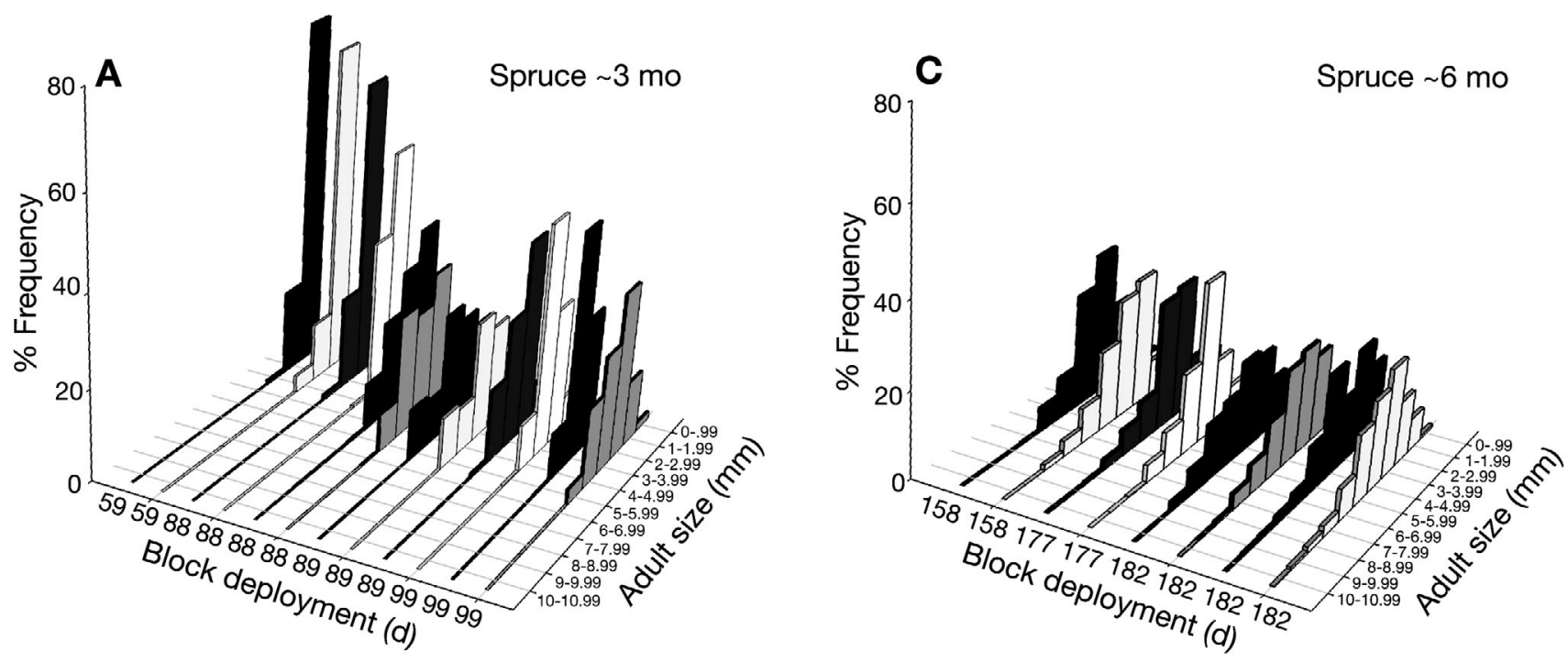

B

Oak $\sim 3$ mo
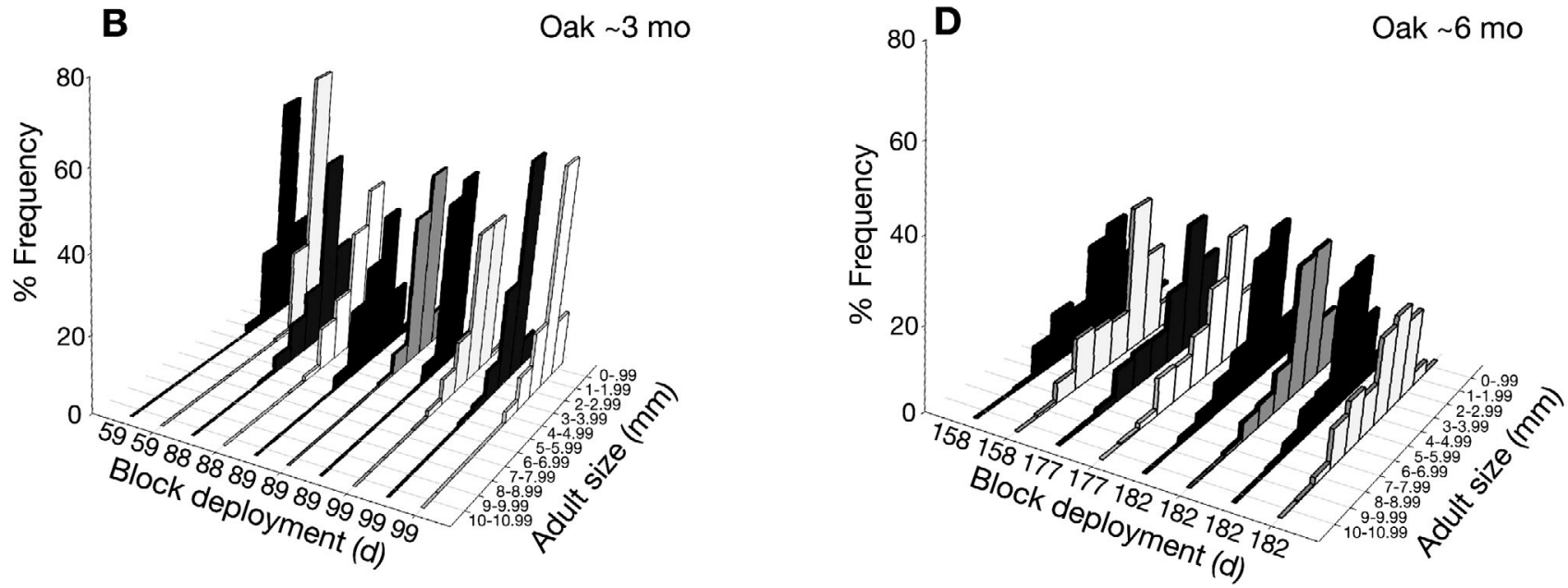

Fig. 6. Xylophaga depalmai. Population structure in both types of wood after 3 mo (60 to 99 d) and 6 mo (158 to 182 d) exposure 
ined (predominantly males) were undergoing gametogenesis. The sex ratio in spruce did not differ significantly from unity (48o; $44 \sigma^{3} ; \chi^{2}=6.38$; not significant), whereas in oak there was a significantly greater number of males (31o; 84 $\left.o^{\prime} ; \chi^{2}=22.35 ; \mathrm{p}=<0.05\right)$, as a result of the high number of young males (Fig. 7)

To test for protandric hermaphroditism, we modified the approach of Purchon (1941) and plotted sex against size (in $\mathrm{mg}$ ) for males and females in spruce and oak (Fig. 7). From these data we saw no evidence of protandric or protogynous hermaphoditism, as both oogenesis and spermatogenesis were found in the smallest individuals and throughout the size range. Although we selected the individuals for gametogenic analysis at random from each block, there appeared to be a significant variation in population size structure between males and females (spruce: Mann-Whitney $U=1723 ; \mathrm{p}=<0.008$; oak: Mann-Whitney $U=2338 ; \mathrm{p}=<0.001$ ), whereas there was no significant difference between females and males in the two different wood types (female: Mann-Whitney $U=$ 1176; $\mathrm{p}=0.438$; male: Mann-Whitney $U=$
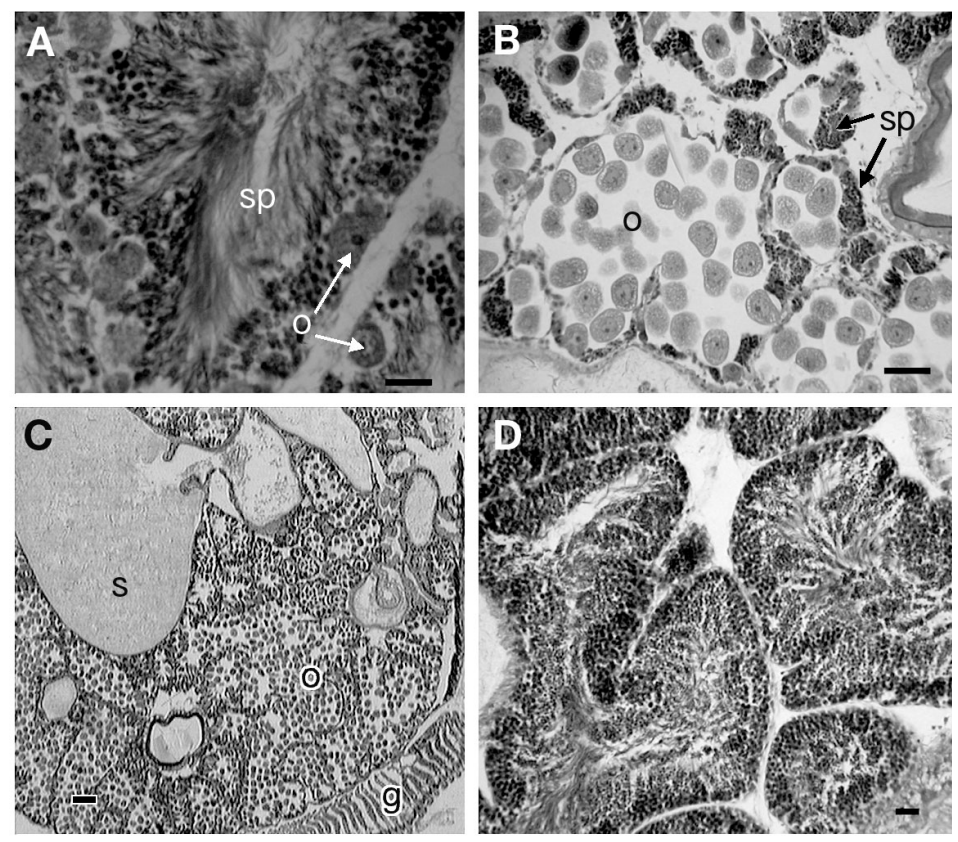

Fig. 8. Xylophaga depalmai. Gametogeniesis. (A) Male-dominated simultaneous hermaphrodism; (B) oocyte-dominated simultaneous hermaphroditism; (C) $106 \mathrm{~d}$ deployment in spruce (mean oocyte size $=28.4$ $\pm 4.44 \mathrm{SD} \mu \mathrm{m})$; (D) male development in (B), $195 \mathrm{~d}$ deployment in oak (mean oocyte size $=20.44 \pm 3.42 \mathrm{SD} \mu \mathrm{m})$. $\mathrm{sp}$ : spermatozoa; o: oocytes; s: stomach; g: gill. Scale bars in $(A, B, D)=50 \mu \mathrm{m}$; in $(C)=100 \mu \mathrm{m}$ 6930; $\mathrm{p}=0.99$ ). We also examined individual Xylophaga depalmai for simultaneous hermaphroditism; 9 ind. out of 250 examined (3.6\%) showed evidence of simultaneous hermaphroditism (Fig. 8A,B). Hermaphrodites ranged in mass from 1.7 to $91.5 \mathrm{mg}$, and were found in both wood types.

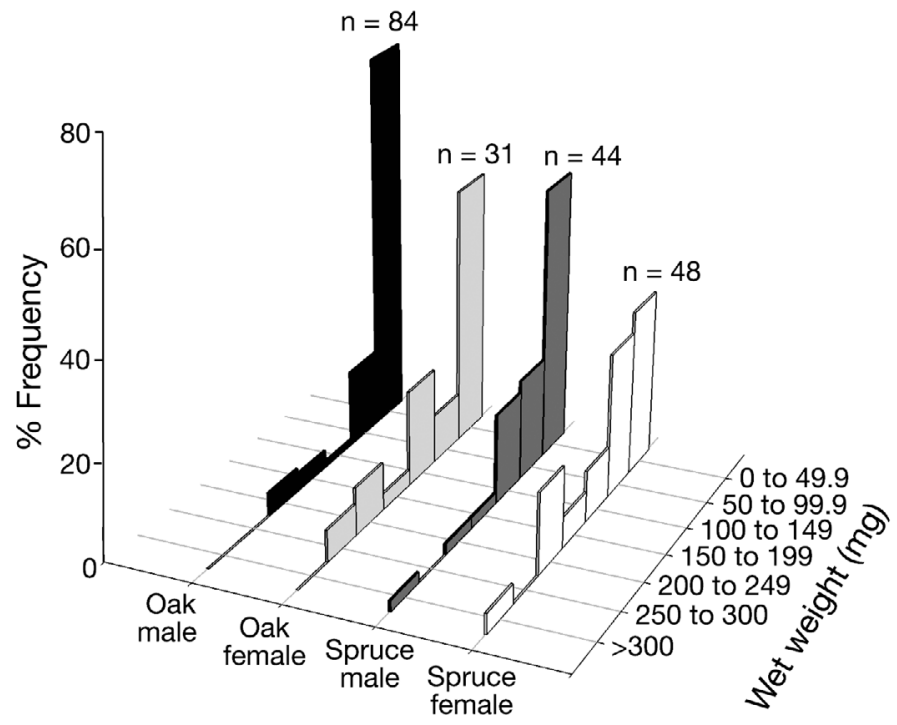

Fig. 7. Xylophaga depalmai. Population structure on sampled blocks separated by wood type and sex to test for occurrence of protandric hermaphroditism
Gametogenesis was very active in all individuals and fecundity was high (Fig. 8C,D), with the gonad occupying a considerable proportion of the body cavity. Maximum oocyte size was ca. $40 \mu \mathrm{m}$. There was no relationship between mean oocyte size and adult weight for either wood type. As individuals of all sizes had both high and low mean oocyte sizes, we infer that gamete production is almost continuous once gametogenesis is initiated. In addition, we examined mean oocyte size as a function of deployment period and time of year of deployment (Fig. 9). There was no relationship between mean oocyte size and time of deployment for either wood type (Fig. 9A). In addition, there appeared to be no relationship between mean oocyte size and the time of year of deployment (Fig. 9B) and time of recovery (Fig. 9C). This reinforces our suggestion that gametogenesis, once initiated, is a quasi-continuous process.

As our data from mean oocyte size suggest quasicontinuous oogenesis, we attempted to determine if there were particular spawning periods by examining oocyte density in the ovary. Our data show considerable variation in oocyte density (Fig. 10) for both wood types over both long and short deployment periods. From these data we infer that there are periods of partial spawning with high density in individuals about to spawn and low density in recently-spawned individuals. 


\section{DISCUSSION}

Many of the organisms associated with wood in the deep sea use the wood for attachment or protection (Wolff 1979). The molluscan subfamily Xylophaginae, however, contains species that are wood-boring specialists in both shallow and deep water. The family
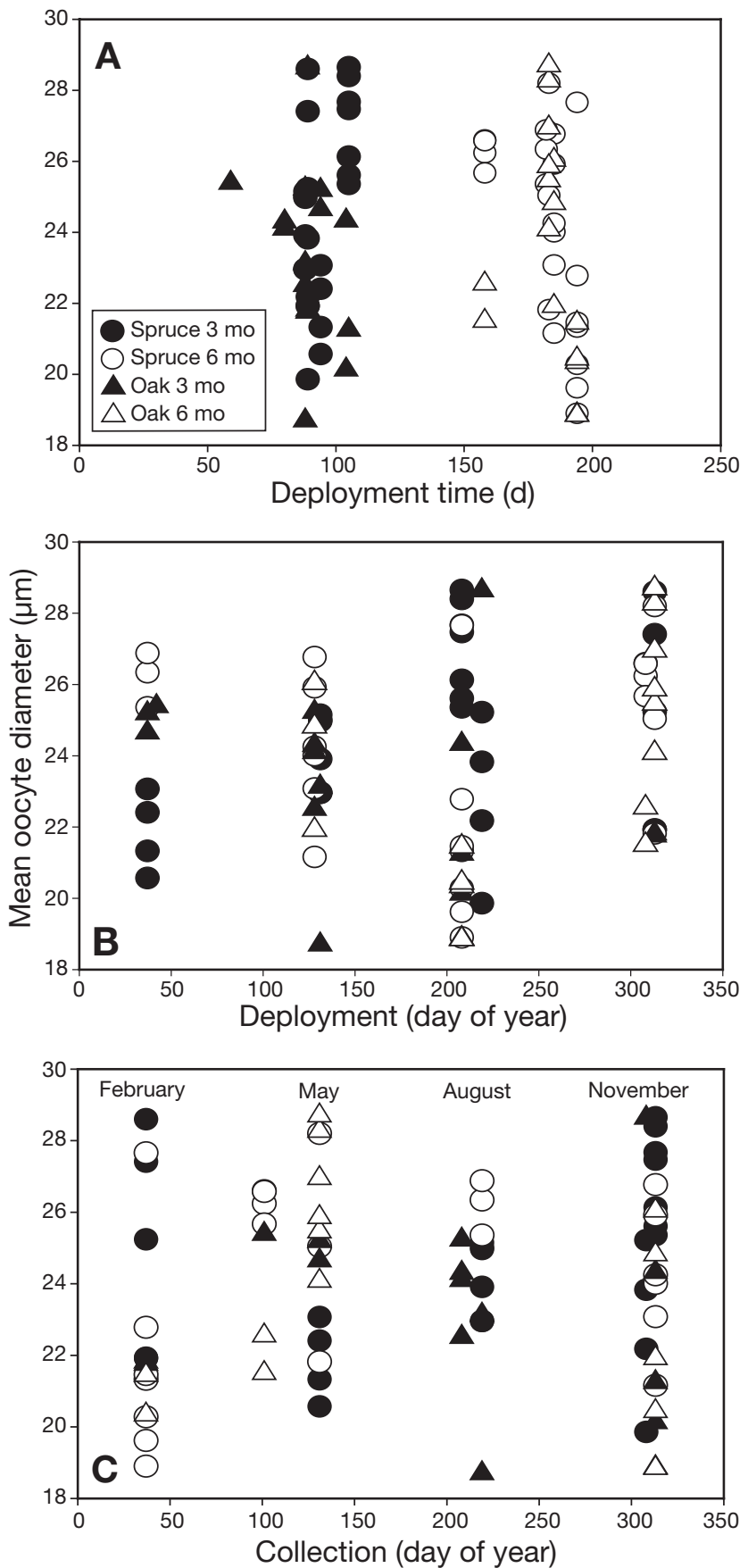

Fig. 9. Xylophaga depalmai. Mean oocyte diameter as a function of (A) block exposure time, (B) day of first exposure and (C) collection day contains three genera (Xylophaga, Xylopholas and Xyloredo) of which Xylophaga is particularly speciose, with new species being regularly described (Knudsen 1961, Harvey 1996, Turner 2002). Species of the genus Xylophaga contain bacterial endosymbionts in the gills that convert cellulose in the wood into digestible carbon and thus make wood available to other metazoans within the deep sea (Distel \& Roberts, 1997).

Over recent years there has been an increased interest in the life histories of wood-boring bivalves (Turner 1973, Norman 1977, Haderlie 1983, Berg et al. 1987, Romey et al. 1991, 1994), because of the potential economic effects (Junqueira et al. 1991). The shallow-water Xylophaga atlantica recruits seasonally to wooden blocks (Berg et al. 1987) and subsequent growth is know to be rapid (Romey et al. 1994). However, relatively little is known of their reproductive activity once settled.

Our experiments were deployed at ca. $500 \mathrm{~m}$ and thus the collection of Xylophaga depalmai in the wooden blocks extended the known depth range of this species by over $300 \mathrm{~m}$. Colonisation was rapid, with the 59 d blocks containing up to ca. 400 colonists, whilst some blocks deployed for 3 mo contained up to ca. 1200 successfully-recruited individuals. Although the data show a great degree of variability, there is some indication that settlement and recruitment were high in the months of May to August, and lowest in the months November to February. Whether, the seasonality observed in our experimental blocks is real or a function of our experimental design must remain unresolved until higher-resolution experiments are carried out. Naturally higher larval availability in the summer months may be related to the hurricane season in the Caribbean, which uproots trees and carries them out to sea. Seasonal settlement occurs in Xylophaga dorsalis (off Millport, Scotland, from December to April), and in X. washingtonia (off Oregon, between

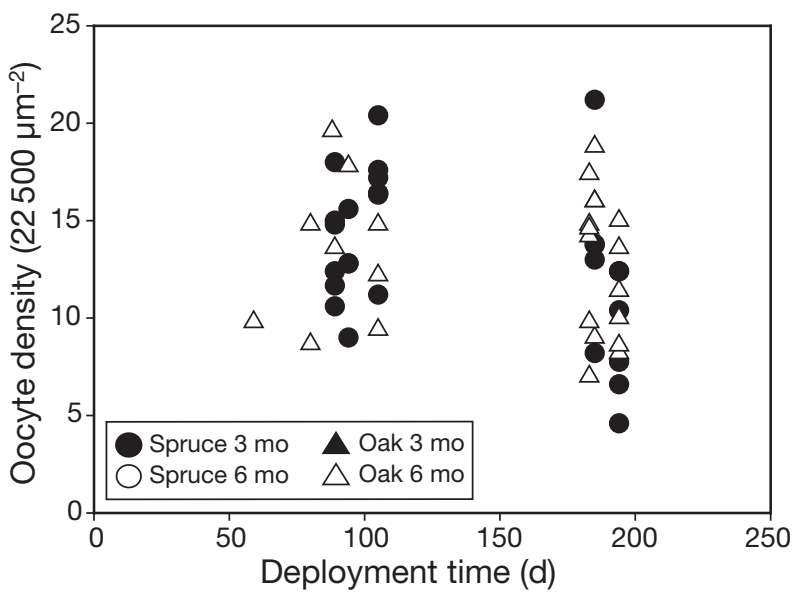

Fig. 10. Xylophaga depalmai. Mean oocyte density in relation to days of deployment 
November and January), whilst in $X$. atlantica settlement is mainly between September and February (Georges Bank populations) or November to April (Mid-Atlantic Bight populations)(Berg et al. 1987, Romey et al. 1991). Seasonal settlement was also found at $1830 \mathrm{~m}$ depth off Woods Hole (Turner 1973). Conversely, Haderlie (1983) reports year-round settlement in $X$. washingtonia off California.

Once settled, growth of Xylophaga depalmai is rapid compared to that of other deep-sea invertebrates (see Gage \& Tyler 1991). The maximum shell diameter after $3 \mathrm{mo}$ is ca. $4 \mathrm{~mm}$, after $6 \mathrm{mo}$ ca. $10 \mathrm{~mm}$. In both types of wood, growth rates of the largest individuals would have been $0.067 \mathrm{~mm} \mathrm{~d}^{-1}$, with a mean growth of ca. $0.03 \mathrm{~mm} \mathrm{~d}^{-1}$. This compares well with 0.027 to $0.085 \mathrm{~mm} \mathrm{~d}^{-1}$ recorded for shelf-depth populations of X. atlantica by Romey et al. (1994), although they did report a growth rate of $0.246 \mathrm{~mm} \mathrm{~d}^{-1}$ in 1 pine block. Such growth rates are rare in the deep sea where growth is generally slow (Gage \& Tyler 1991). The growth rate for $X$. depalmai compares well with $0.056 \mathrm{~mm} \mathrm{~d}^{-1}$ reported for the deep-sea barnacle Poecilasma kaempferi by Lampitt (1990), but is much slower than that reported for the tube worm Riftia pachyptila $\left(2.33 \mathrm{~mm} \mathrm{~d}^{-1}\right)$ at hydrothermal vents by Lutz et al. (1994).

To date, very little is known of reproduction in the family Xylophaginae (Knudsen 1961, Berg et al. 1987), although Purchon (1941) described Xylophaga dorsalis as a protandric hermaphrodite. We have tested the sexuality of $X$. depalmai in a similar way to Purchon's (1941) test of $X$. dorsalis by comparing sex with size. We found no evidence of protandry in $X$. depalmai, and reanalysis of Purchon's (1941) limited data suggests that $X$. dorsalis is not a protandric hermaphrodite either. However, 9 out of 250 individual $X$. depalmai examined did show evidence of simultaneous hermaphroditism. Such a low percentage of hermaphroditism is not unknown in dioecious populations of bivalves (Micaleff \& Tyler 1988, Tyler et al. 2007). Our sampling data also show a sex ratio of unity in the dioecious population of $X$. depalmai in spruce, although in oak there was a significantly higher number of males. In addition, our data reveal no difference in the reproductive population structure among females or males in the two wood types.

The pattern of rapid growth and reproduction observed in Xylophaga depalmai is rare in the deep sea other than at hydrothermal vents (see Lutz et al. 1994), and may be an adaption to resource availability. Rapid growth and reproduction is seen in the deep-water barnacle Poecilasma kaempferi (Lampitt 1990, Green et al. 1994). This barnacle settles on lithodid crabs and must grow and reproduce before the crab undergoes its next ecdysis. In X. depalmai, the limiting resource is wood. Wood is relatively rare in the deep sea and, once colonised by Xylophaga spp., is rapidly eroded. X. depalmi (and other species of Xylophaga) must grow rapidly and have a high reproductive output to ensure sufficient reproductive propagules to colonise new wood entering the ocean.

Xylophaga atlantica develops to the pediveliger stage after $50 \mathrm{~d}$ at ca. $12^{\circ} \mathrm{C}$ and can metamorphose from Day 57 onwards, but may live up to 6 mo in the absence of wood (Culliney \& Turner 1976). Such adaptation would allow free-spawning species of Xylophaga to produce long-lived larvae that are advected away from the adult population to colonise other wood habitats. Larvae from our site at SW Reef would be advected in a $\mathrm{N}-\mathrm{S}$ semidiurnal asymmetric tidal current, with spring tide flows of up to $18 \mathrm{~cm} \mathrm{~s}^{-1}$ mainly to the south. Neap flows rarely exceeded the sensitivity threshold of our current meter $\left(1.5 \mathrm{~cm} \mathrm{~s}^{-1}\right)$ (Young et al. 1993). Thus, larvae of $X$. depalmai would be carried further into the Tongue of the Ocean, before be carried out on the western side.

The rapid settlement, fast growth rate and rapid gametogenesis observed in Xylophaga depalmai is a resource adaptation that may be found in other deepsea metazoan species that rely on ephemeral resources such as Pacific vents, whale falls and biogenic substrata for settlement (Green et al. 1994, Van Dover 2000). Such observations confirm Tyler \& Young's (1992) observation that there is no specific life history pattern typical of the deep sea.

Acknowledgements. The authors thank the captains and crews of the research vessels 'Seward Johnson' and 'Edwin Link' and the pilot and technical support of the 'Johnson Sealink' submersibles. We thank Dr. Janet Voigt (Field Museum, Chicago) for bringing Turner's (2002) monograph to our attention. The manuscript benefited from the comments of 2 unknown referees. This work was completed under NSF grants OCE-9116560, OCE-9633784 and OCE-0118733.

\section{LITERATURE CITED}

Ballard RD (1987) The discovery of the Titanic. Warner Books, New York

Berg CJ Jr, Butman B, Early JA, Turner RD (1987) Seasonal recruitment of marine invertebrates to hard substrates on Georges Bank and the eastern continental shelf of the United States. Nautilus 101:19-24

Culliney JL, Turner RD (1976) Larval development of the deep-water wood boring bivalve, Xylophaga atlantica Richards (Mollusca, Bivalvia, Pholadidae). Ophelia 15: 149-161

Distel DL, Roberts SJ (1997) Bacterial endosymbionts in the gills of the deep-sea wood-boring bivalves Xylophaga atlantica and Xylophaga washingtona. Biol Bull (Woods Hole) 192:253-261

Eckelbarger K, Reish DJ (1972a) Effects of varying temperatures and salinities on settlement, growth, and reproduction of the wood-boring pelecypod, Lyrodus pedicellatus. Bull South Calif Acad Sci 71:116-127 
Eckelbarger K, Reish DJ (1972b) A first report of self fertilization in the wood-boring family Teredinae (Mollusca: Bivalvia). Bull South Calif Acad Sci 71:48-50

Gage JD, Tyler PA (1991) Deep-sea biology: a natural history of organisms at the deep-sea floor. Cambridge University Press, Cambridge

Green A, Tyler PA, Angel MV, Gage JD (1994) Gametogenesis in deep- and surface-dwelling oceanic stalked barnacles from the NE Atlantic Ocean. J Exp Mar Biol Ecol 184: $143-158$

Haderlie E C (1983) Depth distribution and settlement times of the molluscan wood borers Bankia setacea (Tryon, 1863) and Xylophaga washingtonia Bartsch, 1921 in Monerey Bay. Veliger 25:339-342

Harvey R (1996) Deep-water Xylophagidae (Pelycepoda: Pholadacae) from the North Atlantic with descriptions of three new species. J Conchol 35:473-481

Junqueira AOB, Omena EP, da Silva SHG (1991) A comparative study of the methods used to evaluate the activity of Teredinidae mollusks. J Exp Mar Biol Ecol 150:107-115

Knudsen J (1961) The bathyal and abyssal Xylophaga (Pholadidae, Bivalvia). Galathea Rep 5:163-209

Lampitt RS (1990) Directly measured rapid growth of a deepsea barnacle. Nature 345:805-807

Lutz RA, Shank TM, Fornari DJ, Haymon RM, Lilley MD, Von Damm KL, Desbruyères D (1994) Rapid growth at deepsea vents. Nature 371:663-664

Mann R, Gallagher SM (1985) Growth, morphology and biochemical composition of the wood boring molluscs Teredo navalis L., Bankia gouldi (Bartsch) and Nototeredo knoxi (Bartsch) (Bivalvia: Terenidae). J Exp Mar Biol Ecol 85: 229-251

Micaleff S, Tyler PA (1988) Intrafollicular hermaphroditism in the marine mussel Mytilus edulis. Int J Invertebr Reprod Dev 14:4752

Norman E (1977) The geographical distribution and growth of the wood-boring molluscs Teredo navalis L., Psiloteredo

Editorial responsibility: Otto Kinne (Editor-in-Chief), Oldendorf/Luhe, Germany megotara (Hanley) and Xylophaga dorsalis (Turton) on the Swedish west coast. Ophelia 16:233-250

Purchon RD (1941) On the biology and relationships of the lamellibranch Xylophaga dorsalis (Turton). J Mar Biol Assoc UK 25:1-39

Romey WL, Castro KM, DeAtlteris JT, Bullock RC (1991) Recruitment of the deep-sea wood-boring bivalve Xylophaga atlantica Richards. Veliger 34:14-20

Romey WL, Bullock RC, DeAlteris JT (1994) Rapid growth of a deep-sea wood-boring bivalve. Contin Shelf Res 14: 1349-1359

Thiel H (2003) Anthropogenic impacts on the deep sea. In: Tyler PA (ed) Ecosystems of the world, Vol 28. The deep sea. Elsevier, Amsterdam, p 427-478

Turner RD (1973) Wood-boring bivalves, opportunistic species in the deep sea. Science 180:1377-1379

Turner RD (2002) On the subfamily Xylophaginae (Family Pholadidae, Bivalvia, Mollusca). Bull Mus Comp Zool 157: 223-307

Tyler PA (1988) Seasonality in the deep sea. Oceanogr Mar Biol Annu Rev 26:227-258

Tyler PA, Young CM (1992) Reproduction in marine invertebrates in 'stable' environments. Invertebr Reprod Dev 22: 185-192

Tyler PA, Young CM, Dolan E, Arellano SM, Brooke SD, Baker M (2007) Gametogenic periodicity in the chemosynthetic cold-seep mussel 'Bathymodiolus' childressi. Mar Biol 150:829-840, doi 10.1007/S00227-006-0362-9

Van Dover CL (2000) The ecology of deep-sea hydrothermal vents. Princeton, NJ

Wolff T (1979) Macrofaunal utilization of plant remains in the deep sea. Sarsia 64:117-136

Young CM, Tyler PA, Emson RH, Gage JD (1993) Perception and selection of macrophyte detrital falls by the bathyal echinoid Stylocidaris lineata. Deep-Sea Res 40:1475-1486

Zar JH (1996) Biostatistical analysis, 3rd edn. Prentice Hall, Upper Saddle River, NJ

Submitted: August 3, 2006; Accepted: December 4, 2006 Proofs received from author(s): July 19, 2007 